\title{
Control of phytoplankton biomass by dilution and mixed layer depth in the western Weddell-Scotia Confluence
}

\author{
C. D. Hewes ${ }^{1, *}$, C. S. Reiss ${ }^{2}$, M. Kahru ${ }^{3}$, B. G. Mitchell ${ }^{3}$, O. Holm-Hansen ${ }^{1}$ \\ ${ }^{1}$ Marine Biology Research Division, Scripps Institution of Oceanography, University of California, San Diego, \\ 9500 Gilman Drive, La Jolla, California 92093-0202, USA \\ ${ }^{2}$ Antarctic Ecosystem Research Division, Southwest Fisheries Science Center, 8604 La Jolla Shores Drive, La Jolla, \\ California 92037-1508, USA \\ ${ }^{3}$ Integrative Oceanography Division, Scripps Institution of Oceanography, University of California, San Diego, \\ 9500 Gilman Drive, La Jolla, California 92093-0218, USA
}

\begin{abstract}
Hydrographic, nutrient and trace metal (iron, manganese, and aluminum) concentration data, collected as part of a 2-ship survey during austral summer 2004, were used to examine the influence of upwelling and horizontal mixing on phytoplankton biomass in the region of Elephant Island and South Shetland Islands, Antarctica. Temperature/salinity property analysis and changes in trace metal and nutrient concentrations show that horizontal mixing of shelf waters, not upwelling from depth, is correlated with phytoplankton biomass in the upper mixed layer (UML). The interaction between changing UML depth and nutrient and trace metal concentrations in the UML results in a unimodal distribution of phytoplankton biomass centered at intermediate surface salinities of $\sim 34$. Principal component (PC) analysis of hydrographic and chemical observations resolved 3 components that accounted for $99 \%$ of the variability in nutrient and trace metal concentrations. The first PC accounted for a conservative loss of nutrients through dilution across a latitudinal salinity gradient. The second and third PCs separated mixed layer depth and nutrient consumption. Although these 2 PCs accounted for just $20 \%$ of the variability in the data matrix, they accounted for $65 \%$ of the variability in mean phytoplankton biomass, and recreated the unimodal distribution of chlorophyll concentration when modeled across a salinity gradient. We propose that the distribution of phytoplankton biomass is structured by the horizontal mixing of nutrient rich waters, derived from Weddell Sea Shelf Waters, with Antarctic Surface Water that enhances stratification and shoaling of the UML.
\end{abstract}

KEY WORDS: Phytoplankton · Nutrients $\cdot$ Iron $\cdot$ Mixing depth $\cdot$ Salinity $\cdot$ Drake Passage $\cdot$ Weddell Sea

\section{INTRODUCTION}

The Antarctic Circumpolar Current (ACC) is the largest oceanic area on the planet having high concentrations of inorganic macronutrients but low phytoplankton biomass (Chisholm \& Morel 1991). Primary production in the pelagic Southern Ocean is largely controlled by the availability of iron (Boyd 2004, HolmHansen et al. 2005), the major sources of which are coastal sediments (de Baar et al. 1990) and upwelling of the prevailing eastward transport of ACC (Pollard et al. 2002, 2006, Strass et al. 2002, Hiscock et al. 2003). Factors controlling productivity in other areas are less apparent, as the Weddell Sea and coastal vicinities can have high concentrations of iron (Nolting et al. 1991, Westerlund \& Öhman 1991, Sañudo-Wilhelmy et al. 2002), but still contain little chlorophyll (Fig. 1A). In these areas, production may be light-limited (Mitchell \& Holm Hansen 1991) owing to a deep upper mixed layer (UML, also referred to as the wind mixed layer; de Baar et al. 2005). Elevated phytoplankton production is also associated with ice edges (Smith \& Nelson 

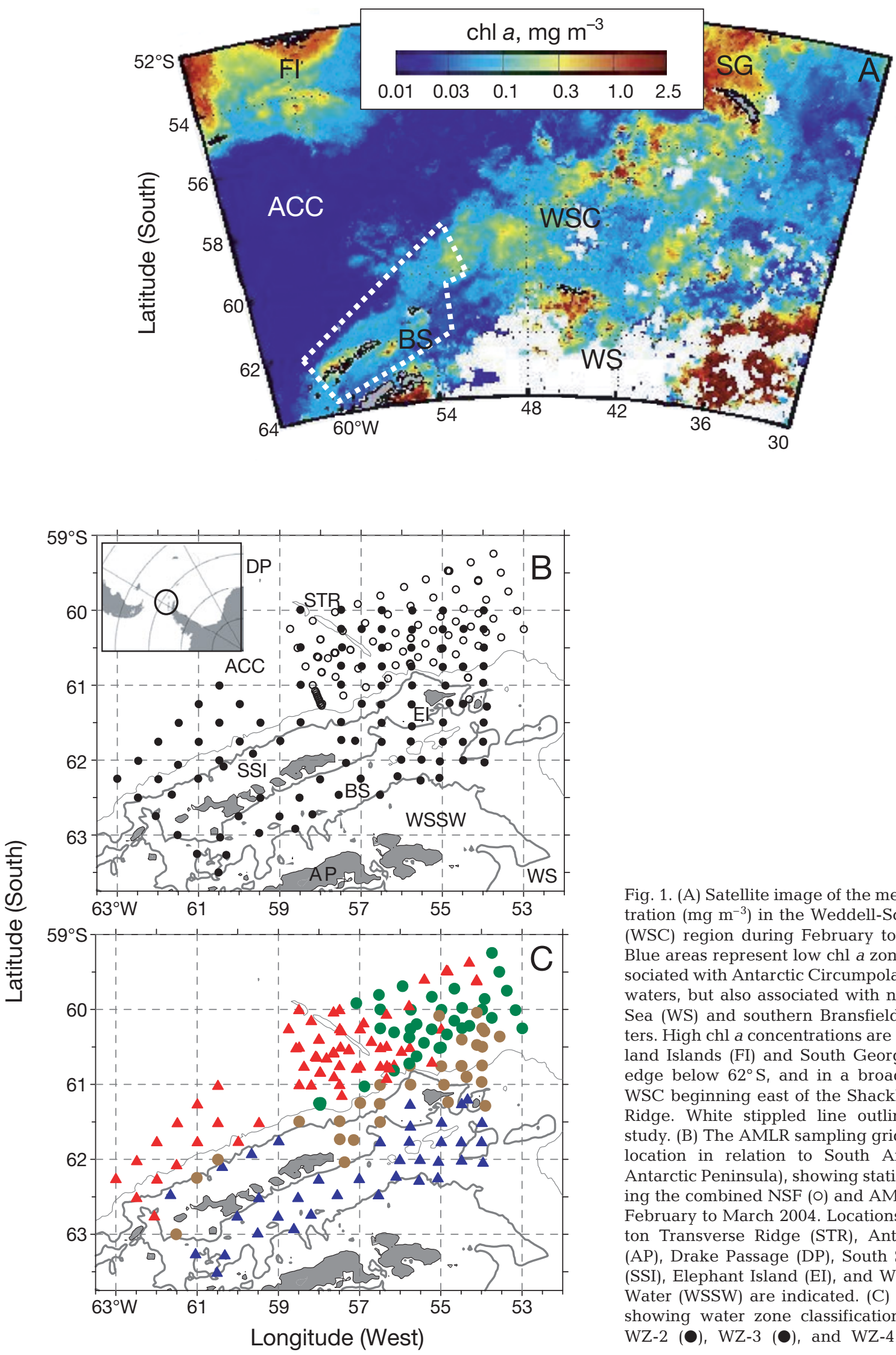

Fig. 1. (A) Satellite image of the mean chl a concentration $\left(\mathrm{mg} \mathrm{m}^{-3}\right)$ in the Weddell-Scotia Confluence (WSC) region during February to March of 2004. Blue areas represent low chl a zones, generally associated with Antarctic Circumpolar Current (ACC) waters, but also associated with northern Weddell Sea (WS) and southern Bransfield Strait (BS) waters. High chl a concentrations are seen in the Falkland Islands (FI) and South Georgia (SG), the ice edge below $62^{\circ} \mathrm{S}$, and in a broad arc across the WSC beginning east of the Shackleton Transverse Ridge. White stippled line outlines the area of study. (B) The AMLR sampling grid (inset indicates location in relation to South America and the Antarctic Peninsula), showing station locations during the combined NSF (O) and AMLR $(\bullet)$ cruises in February to March 2004. Locations of the Shackleton Transverse Ridge (STR), Antarctic Peninsula (AP), Drake Passage (DP), South Shetland Islands (SSI), Elephant Island (EI), and Weddell Sea Shelf Water (WSSW) are indicated. (C) Stations as in B, showing water zone classifications as WZ-1 ( $\mathbf{\Delta})$,

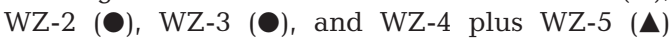


1985) and some coastal waters (Holm-Hansen et al. 1989), indicating that both the availability of light, through UML depth, and iron are essential for phytoplankton blooms.

The Weddell-Scotia Confluence (WSC) mixing zone (extending from the South Shetland Islands to $\sim 20^{\circ} \mathrm{W}$ ) is among the richest areas of the pelagic Southern Ocean (Amos 1984, Tynan 1998). A broad band of elevated chlorophyll a ( $\mathrm{chl}$ a) extends from the Shackleton Transverse Ridge (STR) eastward through the Scotia Sea (Fig. 1). This band of production is independent from ice edge blooms, and from blooms associated with South Georgia. Upwelling-related enhanced production in the WSC is hypothesized to occur (Tynan 1998) with uplifting of isopycnals (Pollard et al. 2002, 2006) at the Southern Boundary of the ACC. This Southern Boundary is found just to the north and east of Elephant Island (Orsi et al. 1995, Holm-Hansen et al. 1997, Amos 2001). Upwelling of nutrient rich Upper Circumpolar Deep Water (UCDW) to the surface (Löscher et al. 1997) might also occur from eddy activity (Letelier et al. 1997), or as the ACC is deflected over and around bathymetric features such as the STR, that could promote diapycnal mixing or provide natural fertilization (Pollard et al. 2002, 2006). A mid-summer phytoplankton bloom develops with regularity immediately east of the STR supporting the hypothesis that upwelling leads to enhanced production (Helbling et al. 1993, Holm-Hansen \& Hewes 2004). However, this is also an area of horizontal mixing, with surface waters exiting the Bransfield Strait to the east of the STR to blend with the ACC (Hofmann et al. 1996, Holm-Hansen \& Hewes 2004). Most of the water in Bransfield Strait is derived from outflow of Weddell waters that pass over the eastern peninsular shelf (Gordon et al. 2000). Water flowing over the shelves of the Antarctic Peninsula and exiting Bransfield Strait will contribute elevated nutrients and trace metals of Weddell Sea origins (Nolting et al. 1991, Westerlund \& Öhman 1991, Sañudo-Wilhelmy et al. 2002) to the ACC by advection and horizontal mixing.

Mixing across shelves in the Elephant Island and South Shetland Islands area creates a broad gradient in water properties that structures the environment at a variety of horizontal and vertical scales (HolmHansen et al. 1997, Amos 2001, Holm-Hansen \& Hewes 2004). How the various environmental factors that comprise this ecosystem are linked may be best approached as a problem of gradient analysis (ter Braak 1987, Legendre \& Legendre 1998). Hydrographic, chemical and biological properties change across gradients in Antarctic environments (e.g. the sea-ice zone, as in Smith \& Nelson 1985), but are not usually examined quantitatively with respect to those gradients. Gradient analysis may be a valuable method to better understand and model controlling factors for the distribution of phytoplankton biomass in this region.

Data from a 2-ship survey conducted in 2004 are used to provide a high-resolution description of hydrographic and chemical conditions that elucidate processes controlling phytoplankton biomass in the surface waters surrounding Elephant Island and South Shetland Islands. We present evidence that high chl a concentration within the western WSC region results primarily from horizontal mixing between the nutrientrich (particularly iron) Weddell Sea shelf waters and the iron-poor but well-stratified Drake Passage ACC. We demonstrate that vertical enrichment of surface waters through upwelling is less important than the dynamic balance that results as Weddell waters are diluted by the ACC. Phytoplankton biomass is maximal where these coastal and pelagic waters interact to produce a shallow UML before concentrations of nutrients and iron are lowered by dilution with ACC waters. Our results have far reaching implications for the development of models that predict the interannual variability of primary production in this region.

\section{MATERIALS AND METHODS}

Field sampling. Data from 2 oceanographic surveys were used to examine phytoplankton biomass in regard to physical and chemical conditions during the austral summer of 2004. The USA Antarctic Marine Living Resource (AMLR) program conducts annual hydrographic surveys aboard the RV 'Yuzhmorgeologiya'; during the 2004 cruise, 92 stations within the historic AMLR grid were occupied between February 21 and March 8. Sampling was also carried out onboard the ARSV 'Laurence M. Gould' (LMG0402, sponsored by the National Science Foundation) from February 15 to March 15, 2004, at stations to the northeast of Elephant Island and on both sides of the Shackleton Transverse Ridge (Fig. 1B). Most of the stations that overlapped between the 2 surveys were north of Elephant Island. For both cruises, water column data were collected with a Sea-Bird SBE9/11+CTD/carousel equipped with a Seabird SBE 43Y dissolved oxygen sensor and 11 (AMLR) or 23 (LMG0402) 101 Niskin sampling bottles with Teflon covered springs. Profiles were limited to a depth of $750 \mathrm{~m}$ or $5 \mathrm{~m}$ above the sea bottom when shallower than $750 \mathrm{~m}$ during AMLR and $1000 \mathrm{~m}$ during the LMG0402 cruise. At least 10 standard sampling depths at each station were made during both cruises at 750 , $200,100,75,50,40,30,20,15,10$ and $5 \mathrm{~m}$; the LMG0402 cruise added samples at $1000 \mathrm{~m}$ as well.

Salinity calibration samples from all stations during AMLR and at intermittent stations during the LMG0402 
cruise were analyzed aboard ship, using a Guideline Portasal salinometer. Close agreement between CTDmeasured salinity and the Portasal values was obtained with an average error of 0.003 (salinity values dimensionless). The CTD-Portasal correlation during the AMLR survey produced an $\mathrm{r}^{2}>0.99(\mathrm{n}=934)$ during the survey.

Chlorophyll a determination. For both cruises, chl a concentration $\left(\mathrm{mg} \mathrm{m}^{-3}\right)$ in the water samples was determined by measurement of chl a fluorescence after extraction in methanol. Sample volumes of $100 \mathrm{ml}$ were filtered through glass fiber filters (Whatmann GFF, $25 \mathrm{~mm}$ ) at reduced pressure (maximal differential pressure of $1 / 3$ atmosphere). The filters with the particulate material were placed in $10 \mathrm{ml}$ of absolute methanol in $15 \mathrm{ml}$ tubes and the photosynthetic pigments extracted at $4^{\circ} \mathrm{C}$ for at least $12 \mathrm{~h}$ The samples were then shaken, centrifuged, and the clear supernatant poured into cuvettes $(13 \times 100 \mathrm{~mm})$ for measurement of chl a fluorescence before and after the addition of 2 drops of $1.0 \mathrm{~N} \mathrm{HCl}$ (Holm-Hansen \& Riemann 1978). Fluorescence was measured using a fluorometer (Turner Designs model 700) that had been calibrated using chl a concentration of a prepared standard (Sigma C-6144) and also with the concentration determined by optical density measurements. Stability of the fluorometer was verified daily by use of a solid-state fluorescence standard (Turner Designs No. 7000-994).

Macronutrient determination. At selected stations, macronutrient (silicate, nitrate, nitrite, ammonia, and phosphate) samples were collected from water bottles into acid washed polypropylene bottles, refrigerated, and measured within 3 to $12 \mathrm{~h}$ using an Alpkem Flow Solution IV System autoanalyzer following the protocol of Gordon et al. (2001).

Dissolved trace metal determination. Water samples for trace metal determination were collected from 37 stations on the 'Laurence M. Gould' using a custombuilt trace metal clean rosette consisting of an epoxy painted aluminum rosette frame holding twelve 121 Go-Flo bottles with a SBE-9/11 CTD system that included an SBE-43 dissolved oxygen sensor. Dissolved trace metal analyses were performed on board ship using filtered sub-samples from the Go-Flo bottles within a few hours of sample collection. Sub-sampling was undertaken using rigorous trace metal protocols. Flow Injection Analysis methods were used for aluminum (Resing \& Measures 1994), iron (Measures et al. 1995), and manganese (Resing \& Mottl 1992). Al and $\mathrm{Mn}$ were determined by 1 -min pre-concentration of sample $(\sim 3 \mathrm{ml})$ onto resin columns (C. I. Measures pers. comm.).

Upper mixed layer depth determination. Depth of the UML was calculated as the depth at which potential density $\left(\sigma_{t}\right)$ differed by $0.05 \mathrm{~kg} \mathrm{~m}^{-3}$ from the mean potential density measured between 5 and $10 \mathrm{~m}$ depth.

Definition of water zones. Within the Elephant Island and South Shetland Islands area, there are 2 primary sources of water that can affect productivity through contribution of nutrients or stability: (1) the ACC and (2) the Weddell Sea outflow. Of less significance are sources from the Bellingshausen Sea, glacial and ice melt, and runoff from land. The ACC is composed, from surface to depth respectively, of Antarctic Surface Water (AASW) and both Upper (UCDW) and Lower (LCDW) Circumpolar Deep Water. During summer, the upper AASW has a warm $\left(2\right.$ to $\left.4^{\circ} \mathrm{C}\right)$ and fresh (salinity $~ 33.8$ ) layer on top of a cold remnant of deep winter water mixing, and contains about $25 \%$ of the silicate concentration found in surface waters of Weddell Sea Shelf water (Holm-Hansen et al. 1997). Importantly, UCDW has relatively low oxygen $\left(<200 \mu \mathrm{mol} \mathrm{kg}{ }^{-1}\right)$ and high nitrate $(\sim 35 \mu \mathrm{M})$ concentrations in comparison to LCDW $\left(\sim 250 \mu \mathrm{mol} \mathrm{kg}^{-1}\right.$ and $30 \mu \mathrm{M}$, respectively) and thus is useful as water mass tracer. Silicate concentrations are about the same for both water masses, ranging from $\sim 60$ to $100 \mu \mathrm{M}$ for depths between 200 and $1000 \mathrm{~m}$ (Orsi et al. 2005). In our study area, much of the Weddell Sea source is Weddell Sea Shelf Water (WSSW) from the eastern shelf of the Antarctic Peninsula (Whitworth et al. 1994, Hofmann et al. 1996, Gordon et al. 2000, Amos 2001). This water source is colder $\left(-0.25^{\circ} \mathrm{C}\right)$, more saline $(>34)$ than the ACC, has no UCDW, and is iron-rich (Westerlund \& Öhman 1991, Sañudo-Wilhelmy et al. 2002).

A water zone (WZ) classification system based on the temperature and salinity (T/S) properties of the water found around the South Shetland Islands has 5 basic zones (Holm-Hansen et al. 1997). The WZ-1 is found in the Western Drake Passage south of the Polar Front and is composed of AASW and both UCDW and LCDW. Importantly, we sub-classify WZ-1 water into a truly Drake Passage ACC water zone, having low surface chl $a$ and a deep chlorophyll maximum (WZ-1A), or a modified ACC water zone (WZ1B) containing higher chl $a$ and nutrient concentrations in the surface and no deep chlorophyll maximum (Holm-Hansen et al. 1997). Bransfield Strait water (WZ-4) and WSSW (WZ-5) are the other extremes, having no UCDW and little, if any, AASW. In our study area, WZ-1 and WZ-5 (or WZ-4 considered as its close proxy) are the 2 primary sources from which mixtures, designated WZ-2 and WZ-3, are composed (Fig. 1C). WZ-3 waters are found predominately along the northern and northeastern shelf and shelf-break of Elephant Island and the South Shetland Islands, with upper water column properties similar to, and thus probably derived from, WZ-4. In deeper 
waters, WZ-3 has water mass characteristics associated with LCDW, probably derived from Weddell sources originating from leakage through gaps in the central South Scotia Ridge to flow southwest along the shelf-break (Whitworth et al. 1994, Heywood et al. 2004), and sometimes referred to as an extension of the Polar Slope Current (Nowlin \& Zenk 1988, Hofmann et al. 1996). Furthermore, silicate:nitrate ratios from deeper casts (500 to $1000 \mathrm{~m}$ ) of WZ-3 resemble those from the Weddell Sea at similar salinities and densities (C. D. Hewes unpubl.). WZ-2 has a complicated vertical structure owing to interleaving layers between UCDW and LCDW, and for which isopycnal mixing is reported to occur at depth (Holm-Hansen et al. 1997, Amos 2001).

Data analysis. A combination of oceanographic approaches were used to resolve the distribution of phytoplankton biomass in relation to hydrography, including property-property plots to examine mixing among water masses, and both linear and curvilinear least squares regression to examine changes in water column properties. We also examined the variability in the concentration of nutrients and trace metals with respect to different isopycnal surfaces in the water column. In upwelling situations the isopycnal surfaces can vary greatly with depth, providing evidence for vertical transport of nutrients that follow these isopycnals into the euphotic zone (Pollard et al. 2002, 2006). If vertical transport of controlling substance(s) is responsible for elevating phytoplankton biomass, then nutrient concentrations should follow patterns consistent with upwelling, including discontinuities in surface properties due to Ekman pumping (Hiscock et al. 2003), or property surfaces following isopycnals.

Principal component analysis (PCA, analogous to empirical orthogonal function [EOF] analysis, Priesendorfer 1988) was used to partition the variability in salinity, UML, $\mathrm{N}_{\text {total }}$ (nitrate + ammonia), silicate and phosphate data into underlying orthogonal (uncorrelated) principal components (PCs). Prior to applying the PCA, data were normalized by subtracting the mean and dividing by the variance for each variable, facilitating comparisons amongst data types and data ranges (Legendre \& Legendre 1998). Resulting PCs (modes) explain the variability in the spatial distribution of nutrients, and describe an 'environmental space' related to the variability in nutrients and hydrography for the South Shetland Islands. Each PC was also correlated with other abiotic variables to resolve potential inter-dependencies. A reduced set of variables was used to prevent biases resulting from co-linearity for the PCA (ter Braak 1987). Stepwise and multiple regression of these PCs was then used to best reconstruct phytoplankton biomass in relation to nutrient concentrations and UML depth.

\section{RESULTS}

\section{Water mass analysis}

Average T/S properties of the 6 water zones (WZ-1A to WZ-5) (Fig. 2A) encountered during our surveys indicate that they are composed of mixtures of various water masses. However, averaging of CTD profiles for WZ-2 waters (Fig. 2A) is particularly misleading because the averaged trace appears to be intermediate between WZs -1 and -3 and contains a mixture of both UCDW and LCDW waters. Close examination of an individual trace (Fig. 2B) shows that the variability in $\mathrm{T} / \mathrm{S}$ properties associated with the WZ-2 waters is largely a function of interleaving for waters having different temperatures between 200 and $500 \mathrm{~m}$. Based on this variability, we further categorized WZ-2 waters with respect to their temperature at potential densities of $27.6( \pm 0.05) \mathrm{kg} \mathrm{m}^{-3}$. Casts where the water column temperature at this density was $>1{ }^{\circ} \mathrm{C}$ were designated WZ-2A (UCDW present) and the remainder designated WZ-2B (UCDW absent). Thus, by comparing temperatures at the $27.6 \mathrm{~kg} \mathrm{~m}^{-3}$ isopycnal, the water column of all stations could be classified as 'ACC-like' or 'Weddell-like' reflecting the presence or absence of warm UCDW (see Fig. 2A).

Evidence that stations classified as either WZ-2A or WZ-2B are actually areas of mixing and upwelling at depth is found when dissolved oxygen is plotted vs. the depth of the $27.6 \mathrm{~kg} \mathrm{~m}^{-3}$ isopycnal (Fig. 2C, average of $1 \mathrm{~m}$ binned data with $\sigma_{\mathrm{t}}=27.6 \pm 0.02 \mathrm{~kg} \mathrm{~m}^{-3}$ and a narrower range than used to partition WZ-2A and WZ-2B waters). The presence/absence of UCDW that distinguished the WZs in T/S space (Fig. 2B) is also identified by the oxygen concentration; warm, salty UCDW exhibits an oxygen minimum $\left(\sim 170 \mu \mathrm{mol} \mathrm{kg}{ }^{-1}\right)$ in ACC waters. The $27.6 \mathrm{~kg} \mathrm{~m}^{-3}$ isopycnal shoals from $350 \mathrm{~m}$ to about $150 \mathrm{~m}$ from WZ-1A (ACC) to WZ-2A waters, and dissolved oxygen increases by $\sim 20 \mu \mathrm{mol} \mathrm{kg}{ }^{-1}$. Between WZ-2B and WZ-4 the depth of the $27.6 \mathrm{~kg} \mathrm{~m}^{-3}$ isopycnal fluctuated around $200 \mathrm{~m}$, but dissolved oxygen increased from 200 to $270 \mu \mathrm{mol} \mathrm{kg} \mathrm{kg}^{-1}$ before isopycnals shoaled again to $\sim 75 \mathrm{~m}$ for WZ-5 (where high dissolved oxygen occurs owing to ventilation with the surface). Thus, 'Weddell-like' waters contained higher dissolved oxygen concentrations at a shallower isopycnal depth indicating their WSSW source (and lack of UCDW), while 'ACC-like' waters (WZ-1A) had low concentrations of oxygen as found in the UCDW. The pattern of oxygen concentration vs. depth along this isopycnal surface follows the order of the water column classification, indicating that the water zones form a continuum of changing physical conditions.

Evidence that mixing between the water zones occurs is shown when oxygen is plotted against salinity 

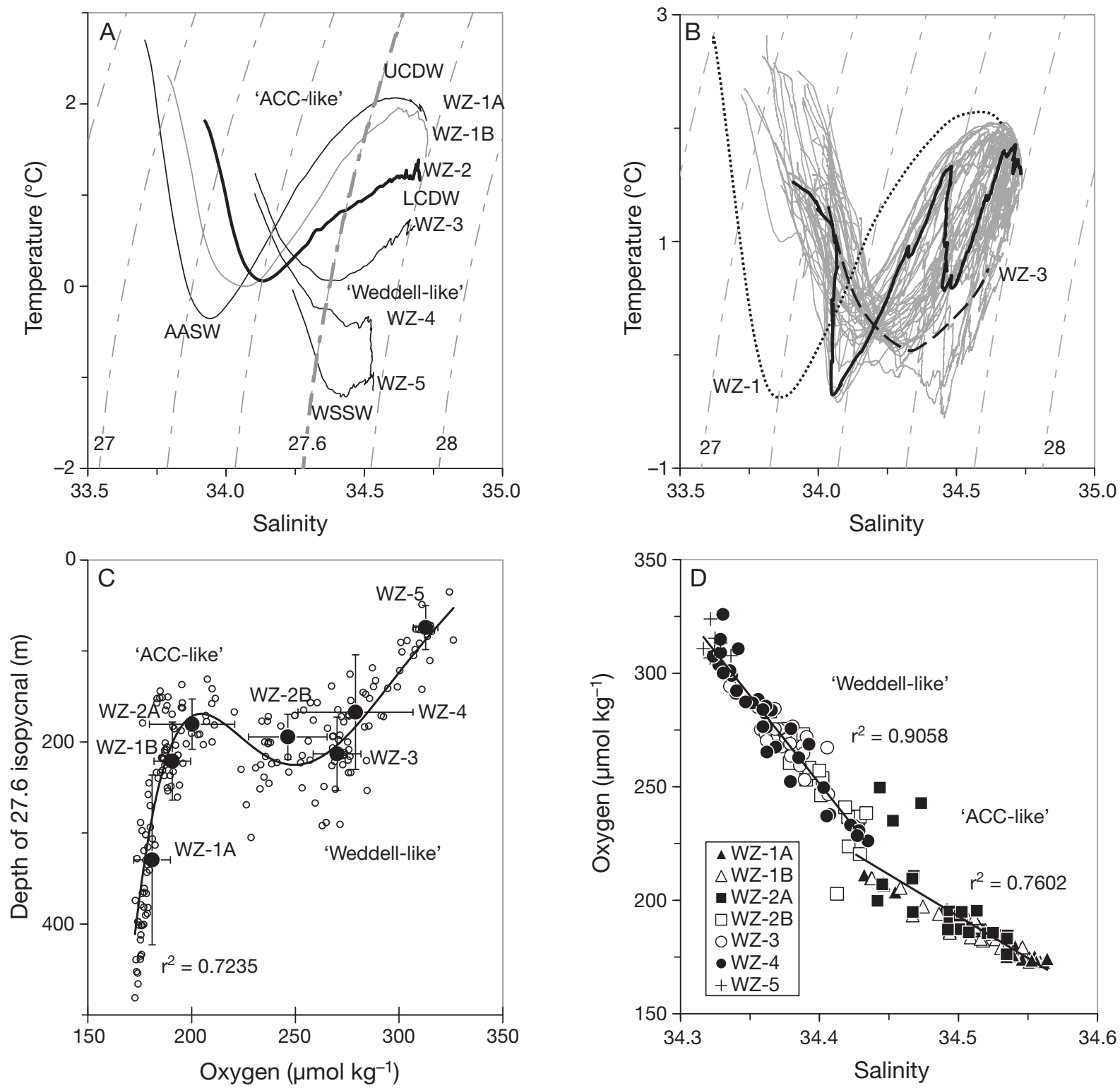

Fig. 2. Physical and chemical characteristics of the 5 water zones found in the AMLR sampling grid. (A) Average temperature versus salinity characteristics of 5 water zones (and sub-classifications of WZ-1 and WZ-2) classified in the study area (numbers of stations used for each average for WZ-1A through WZ-4 are given in Table 1 ; WZ-5 included 7 stations). Isopycnal intervals $\left(\sigma_{\mathrm{T}}\right)$ in temperature/salinity space are indicated as stippled lines; a thicker line indicates the $27.6 \mathrm{~kg} \mathrm{~m}^{-3}$ isopycnal. A thick solid line indicates the average characteristics for WZ-2. (B) WZ-2 temperature versus salinity relationships for all casts (gray lines), and in relation to average WZ-1A (stippled line) and WZ-3 (dashed line) waters. A station cast representing WZ-2A (thick solid line) is shown as an example of variability in isopycnal mixing occurring in the Shackleton Front. (C) Oxygen concentration along the average $27.6 \mathrm{~kg} \mathrm{~m}^{-3}$ isopycnal surface (see Table 1 for details) and the depth at which this occurred for all stations (O). Mean (@) and standard deviations (lines) for each of the water zones are shown. Curved line is 3rd order polynomial best fit to station data. (D) Oxygen versus salinity concentrations along the $27.6 \mathrm{~kg} \mathrm{~m}^{-3}$ isopycnal surface. U(L)CDW: Upper (Lower) Circumpolar Deep Water; AASW: Antarctic Surface Water. See Fig. 1 for other abbreviations

at the $27.6 \mathrm{~kg} \mathrm{~m}^{-3}$ isopycnal (Fig. 2D). The relationship is indicative of mixing between cold, less-saline coastal waters and the warm, high salinity source from the UCDW. Yet, a break between 'Weddell-like' and 'ACC-like' waters is observed. Analysis of covariance showed that the 2 slopes for oxygen vs. salinity regres- sions differ (Fig. 2D, ANCOVA, p < 0.05) between stations classified as 'ACC-like' (WZ-1A, WZ-1B, and WZ-2A) and 'Weddell-like' (WZ-2B, WZ-3, WZ-4). These data indicate that isopycnal mixing occurs within either 'Weddell-like' or 'ACC-like' waters, but little mixing occurs between them at depth for this 
Table 1. Average biological, chemical and physical characteristics of the water columns for 4 water zones classified in the Elephant Island and South Shetland Islands region as related to isopycnal surfaces of 27.6 and $27.4 \mathrm{~kg} \mathrm{~m}^{-3}$. Number of stations and average isopycnal depth $(\mathrm{m})$ is given for each water zone. Average temperature, salinity and oxygen from CTD data binned at $1 \mathrm{~m}$ intervals, and silicate, silicate:nitrate ratio, $\mathrm{Al}, \mathrm{Fe}$, and $\mathrm{Mn}$ from discrete water bottle samples (number of nutrient and trace metal [TM] samples given). These data for isopycnal surfaces were obtained at depths at which density was $\sigma_{\mathrm{t}}=27.6 \pm 0.05$ and

$$
\sigma_{\mathrm{t}}=27.4 \pm 0.02 \mathrm{~kg} \mathrm{~m}^{-3}
$$

\begin{tabular}{|c|c|c|c|c|c|c|}
\hline \multirow{3}{*}{$\begin{array}{l}\text { Water zone: } \\
\text { Isopycnal: }\end{array}$} & \multirow{3}{*}{1} & & \multirow{2}{*}{\multicolumn{2}{|c|}{ - 'ACC-like' }} & \multirow[b]{3}{*}{27.6} & \multirow[b]{3}{*}{274} \\
\hline & & & & & & \\
\hline & & 27.4 & 27.6 & 27.4 & & \\
\hline No. of stations & \multicolumn{2}{|c|}{49} & \multicolumn{2}{|c|}{31} & \multicolumn{2}{|c|}{25} \\
\hline Depth & $362 \pm 96$ & $147 \pm 32$ & $237 \pm 55$ & $104 \pm 18$ & $192 \pm 42$ & $84 \pm 20$ \\
\hline Temp $\left({ }^{\circ} \mathrm{C}\right)$ & $2.0 \pm 0.3$ & $0.9 \pm 0.7$ & $1.7 \pm 0.3$ & $0.1 \pm 0.5$ & $1.5 \pm 0.4$ & $0.3 \pm 0.3$ \\
\hline Salinity & $34.54 \pm 0.05$ & $34.20 \pm 0.07$ & $34.51 \pm 0.05$ & $34.14 \pm 0.06$ & $34.50 \pm 0.06$ & $34.15 \pm 0.04$ \\
\hline $\mathrm{O}_{2}\left(\mathrm{ml} \mathrm{l}^{-1}\right)$ & $4.1 \pm 0.2$ & $5.9 \pm 0.5$ & $4.3 \pm 0.3$ & $6.5 \pm 0.4$ & $4.5 \pm 0.5$ & $6.6 \pm 0.5$ \\
\hline No. of nutrient samples & 7 & 22 & 2 & 15 & 11 & 32 \\
\hline $\mathrm{SiOH}(\mu \mathrm{M})$ & $78 \pm 1$ & $50 \pm 6$ & $72 \pm 1$ & $55 \pm 6$ & $74 \pm 3$ & $58 \pm 6$ \\
\hline $\mathrm{SiOH}: \mathrm{NO}_{3}$ & $2.2 \pm 0.0$ & $1.5 \pm 0.1$ & $2.1 \pm 0.1$ & $1.8 \pm 0.2$ & $2.1 \pm 0.1$ & $1.9 \pm 0.2$ \\
\hline No. of TM samples & 4 & 14 & 3 & 11 & 3 & 17 \\
\hline $\mathrm{Al}(\mathrm{nM})$ & $1.3 \pm 0.1$ & $1.2 \pm 0.3$ & $1.1 \pm 0.3$ & $1.1 \pm 0.1$ & $1.0 \pm 0.1$ & $1.1 \pm 0.1$ \\
\hline $\mathrm{Fe}(\mathrm{nM})$ & $0.66 \pm 0.19$ & $0.35 \pm 0.16$ & $0.47 \pm 0.08$ & $0.35 \pm 0.16$ & $0.65 \pm 0.25$ & $0.58 \pm 0.41$ \\
\hline \multirow[t]{3}{*}{$\mathrm{Mn}(\mathrm{nM})$} & $0.21 \pm 0.09$ & $0.17 \pm 0.07$ & $0.39 \pm 0.18$ & $0.87 \pm 0.66$ & $0.42 \pm 0.28$ & $1.12 \pm 0.66$ \\
\hline & \multicolumn{2}{|c|}{$2 \mathrm{~B}$} & \multicolumn{2}{|c|}{- 'Weddell-like' } & \multirow[b]{2}{*}{27.6} & \\
\hline & 27.6 & 27.4 & 27.6 & 27.4 & & 27.4 \\
\hline No. of stations & \multicolumn{2}{|c|}{22} & \multicolumn{2}{|c|}{29} & \multicolumn{2}{|c|}{35} \\
\hline Depth & $203 \pm 37$ & $82 \pm 24$ & \multicolumn{2}{|c|}{29} & $195 \pm 71$ & $61 \pm 41$ \\
\hline Temp $\left({ }^{\circ} \mathrm{C}\right)$ & $0.5 \pm 0.4$ & $0.5 \pm 0.3$ & $0.1 \pm 0.2$ & $0.7 \pm 0.3$ & $-0.1 \pm 0.5$ & $0.6 \pm 0.2$ \\
\hline Salinity & $34.42 \pm 0.05$ & $34.16 \pm 0.03$ & $34.38 \pm 0.04$ & $34.18 \pm 0.03$ & $34.38 \pm 0.04$ & $34.17 \pm 0.02$ \\
\hline $\mathrm{O}_{2}\left(\mathrm{ml} \mathrm{l}^{-1}\right)$ & $5.6 \pm 0.5$ & $6.9 \pm 0.3$ & $6.1 \pm 0.3$ & $7.1 \pm 0.2$ & $6.3 \pm 0.6$ & $7.1 \pm 0.3$ \\
\hline No. of nutrient samples & 9 & 28 & 6 & 33 & 11 & 21 \\
\hline $\mathrm{SiOH}, \mu \mathrm{M}$ & $78 \pm 2$ & $67 \pm 4$ & $81 \pm 2$ & $72 \pm 2$ & $78 \pm 2$ & $72 \pm 1$ \\
\hline $\mathrm{SiOH}: \mathrm{NO}_{3}$ & $2.4 \pm 0.1$ & $2.3 \pm 0.2$ & $2.6 \pm 0.1$ & $2.5 \pm 0.1$ & $2.5 \pm 0.0$ & $2.5 \pm 0.0$ \\
\hline No. of TM samples & 4 & 15 & 4 & 13 & 7 & 13 \\
\hline $\mathrm{Al}(\mathrm{nM})$ & $1.4 \pm 0.0$ & $1.6 \pm 0.2$ & $1.9 \pm 0.3$ & $2.0 \pm 0.4$ & $1.6 \pm 0.2$ & $2.0 \pm 0.7$ \\
\hline $\mathrm{Fe}(\mathrm{nM})$ & $1.18 \pm 0.77$ & $1.15 \pm 0.53$ & $1.97 \pm 0.06$ & $1.86 \pm 0.31$ & $2.85 \pm 0.41$ & $3.05 \pm 1.50$ \\
\hline $\mathrm{Mn}(\mathrm{nM})$ & $1.48 \pm 1.03$ & $2.78 \pm 1.32$ & $2.15 \pm 0.34$ & $2.47 \pm 0.23$ & $1.64 \pm 0.14$ & $4.23 \pm 3.25$ \\
\hline
\end{tabular}

isopynal surface. This 'break' between 2 mixing zones indicates the presence of a third end member. This third end member is derived from LCDW (Fig. 2A) originating from outflow of Weddell Sea water through gaps in the central South Scotia Ridge, as evidenced by the change in temperature between WZ-2A and WZ-2B of $1.5^{\circ} \mathrm{C}$ (Table 1 ). Although oxygen may indicate a continuum along the $27.6 \mathrm{~kg} \mathrm{~m}^{-3}$ isopycnal surface (Fig. 2C), concentrations may in fact be disjointed as a frontal feature that separates 'Weddell-like' and 'ACC-like' sources.

\section{Nutrient and trace metal distribution}

The 'break' between 'Weddell-like' and 'ACC-like' waters was also found in patterns of both silicate and trace metal concentrations (Table 1, averaged bottle data with potential density $=27.6 \pm 0.05 \mathrm{~kg} \mathrm{~m}^{-3}$ ). At this isopycnal, concentrations of aluminum, iron and manganese were low within WZ-2A and ACC waters, and higher in WZ-2B. This indicates that, in addition to the absence of UCDW, the chemistry of WZ-2B stations more closely resembles water having WSSW origin. The ratio of silicate:nitrate also differs on either side of this 'break', indicating that 'ACC-like' waters contain more nitrate $(\sim 5 \mu \mathrm{M})$ but similar silicate concentrations as UCDW. Based on differences in oxygen, nutrient, and trace metal concentrations, this 'break' appears to be a front that divides 2 bodies of water, and on each side, independent dynamical exchanges occur in hydrographic and chemical properties. Waters classified as either WZ-2A or WZ-2B should be designated to the frontal zone that encompasses the Southern 
Boundary of the ACC. Importantly, nutrient and trace metal, as well as oxygen data provide evidence that little exchange or upwelling from UCDW into 'Weddell-like' waters occurred along the $27.6 \mathrm{~kg} \mathrm{~m}^{-3}$ isopycnal surface.

Although WZs are separated from each other at $27.6 \mathrm{~kg} \mathrm{~m}^{-3}$ in T/S space, they do tend to converge around the $27.4 \sigma_{\mathrm{t}}$ (Fig. 2A). It is evident that when the nutrients and trace metal concentrations are examined at the $27.4 \sigma_{\mathrm{t}}$ (mean values $\pm 0.05 \mathrm{~kg} \mathrm{~m}^{-3}$ ) isopycnal, upwelling within the ACC is not responsible for the concentrations found in the UML (Table 1). A third end member is not obvious, as was found to occur deeper in the water column. The concentrations of macronutrients were generally lower, as was salinity, within this shallower isopycnal surface than found at higher densities. The depth of this isopycnal surface is deeper than the UML in WZ-1A (43 $\pm 12 \mathrm{~m}, \mathrm{n}=53)$ as well as WZ-1B and WZ-2 $(36 \pm 14 \mathrm{~m}, \mathrm{n}=77)$, and is about the depth of the pycnocline for WZ-3 and WZ-4 (54 $\pm 19 \mathrm{~m}$, $\mathrm{n}=71$ ) water zones. This indicates that the lower concentrations of nutrients and trace metals are not a function of phytoplankton consumption as most biomass occurs within the UML (above the pycnocline). If upwelling (greatest in WZ-1B and WZ-2A, Fig 2C) had extended into the surface layers, chemical signatures in relation to salinity of deeper water would be present, and this is not the case. For example, Mn concentrations along the surface in WZ-2B were twice those at the adjacent WZ-2A (Table 1) and even Fe was several times higher in 'Weddell-like' than in 'ACC-like' waters. However, because nutrients and trace metals appear to follow water zones across this $27.4 \mathrm{~kg} \mathrm{~m}^{-3}$ isopycnal surface, isopycnal mixing might occur. Yet, low concentrations of manganese and iron are found in WZ-1A waters at both the 27.4 and $27.6 \mathrm{~kg} \mathrm{~m}^{-3}$ isopycnals. Therefore, if isopycnal mixing occurs, it is obvious that the high concentrations of silicate and iron did not originate from the ACC, but instead originated from WSSW.

Having established that there is a definitive break (Fig. 2D) between the adjacent WZ-2A and WZ-2B waters that separates 'ACC-like' and 'Weddell-like' sources at depth, and that chemical concentrations vary greatly across this break (Table 1), we can compare iron and nutrient concentrations within the UML to examine how these vary in relation to salinity. Macronutrients (nitrate, phosphate and silicate) and trace metals (iron, manganese, and aluminum) in the UML were all positively correlated with salinity $\left(\mathrm{r}^{2}>\right.$ 0.23 to $0.95, \mathrm{p}<0.001)$. Ammonia concentrations were highest in WZ-1A and WZ-3 waters, but were not highly correlated with salinity ( $p>0.05)$. In contrast, more than $95 \%$ of the variability in silicate concentration was explained by change in salinity (Fig. 3A). This suggests that silicate is relatively conservative in relation to salinity in the WSC vicinity, and can be used as a proxy for passive conservative processes like dilution and mixing. The only large deviations from linearity were at $\sim 33.8$ (WZ-1) where silicate drops off the mixing line and within WZ-4 where it levels off.

The relationship between $N_{\text {total }}$ (nitrate + ammonia concentrations) and salinity (Fig. 3B) was more variable than for silicate, and considerable deviation in $\mathrm{N}_{\text {total }}$ occurred at intermediate salinities. This indicates that both conservative (dilution) and non-conservative (consumption) losses occurred. This is especially evident in WZ-1B where the mean $\mathrm{N}_{\text {total }}$ was $2.2 \mu \mathrm{M}$ less than WZ-1A waters, indicating substantial nutrient consumption. Phosphate concentrations co-varied significantly with both nitrate $\left(\mathrm{n}=194, \mathrm{r}^{2}>0.95\right)$ and with $\mathrm{N}_{\text {total }}\left(\mathrm{n}=194, \mathrm{r}^{2}>0.97\right.$ ), and extensive testing did not reveal any significant difference between WZs for the nitrate:phosphate ratio of $14.8 \pm 0.3$. Further discussions consider only nitrogen concentrations as phosphate is highly correlated with nitrogen.

Iron concentrations also increased with salinity in the UML (Fig. 3C) similar to both $\mathrm{N}_{\text {total }}$ and silicate. At a salinity $<34$ ('ACC-like'), there was a rapid drop in iron concentrations to $<0.5 \mathrm{nM}$. Iron and $\mathrm{N}_{\text {total }}$ concentrations in the UML co-varied ( $\mathrm{n}=62, \mathrm{r}^{2}>0.89$ ), one indicator that the non-conservative processes in both were coupled. Importantly, for our data, this also suggests that $\mathrm{N}_{\text {total }}$ in the UML is a good proxy variable for iron concentration.

The UML depth increased with increasing salinity ( $\mathrm{n}=196, \mathrm{r}^{2}>0.25$ ), but in a complicated manner (Fig. 3D). Within the ACC (WZ-1) where salinity, silicate, $\mathrm{N}_{\text {total }}$ and iron were low, the UML depth was shallow $(\sim 30$ to $50 \mathrm{~m})$. In contrast, WZ-4 and WZ-5 had high concentrations of nutrient and trace metals, but the water column had deep UMLs, especially at salinities $>34.2$ where the UML ranged from 50 to $>100 \mathrm{~m}$ depth. The shallowest UML was found in WZ-2 (for this data subset, $\mathrm{n}=31,34 \pm 14 \mathrm{~m}$; salinities 33.9 to 34.1 in Fig. 2C).

\section{Phytoplankton biomass, UML depth and nutrients}

On average, the highest chl a concentrations were observed at salinities between 33.9 and 34.1, independent of the ship from which samples were taken (Fig. 4). The AMLR cruise occupied more of the Bransfield Strait to the southwest, while the LMG0402 cruise sampled more of the ACC to the northeast (see Fig. 1B). This explains some of the difference in variability across the salinity gradient between the 2 surveys. The modes for these chl a distributions (Fig. 4, 2nd order polynomials, $\mathrm{p}<0.001$ ) occurred at 

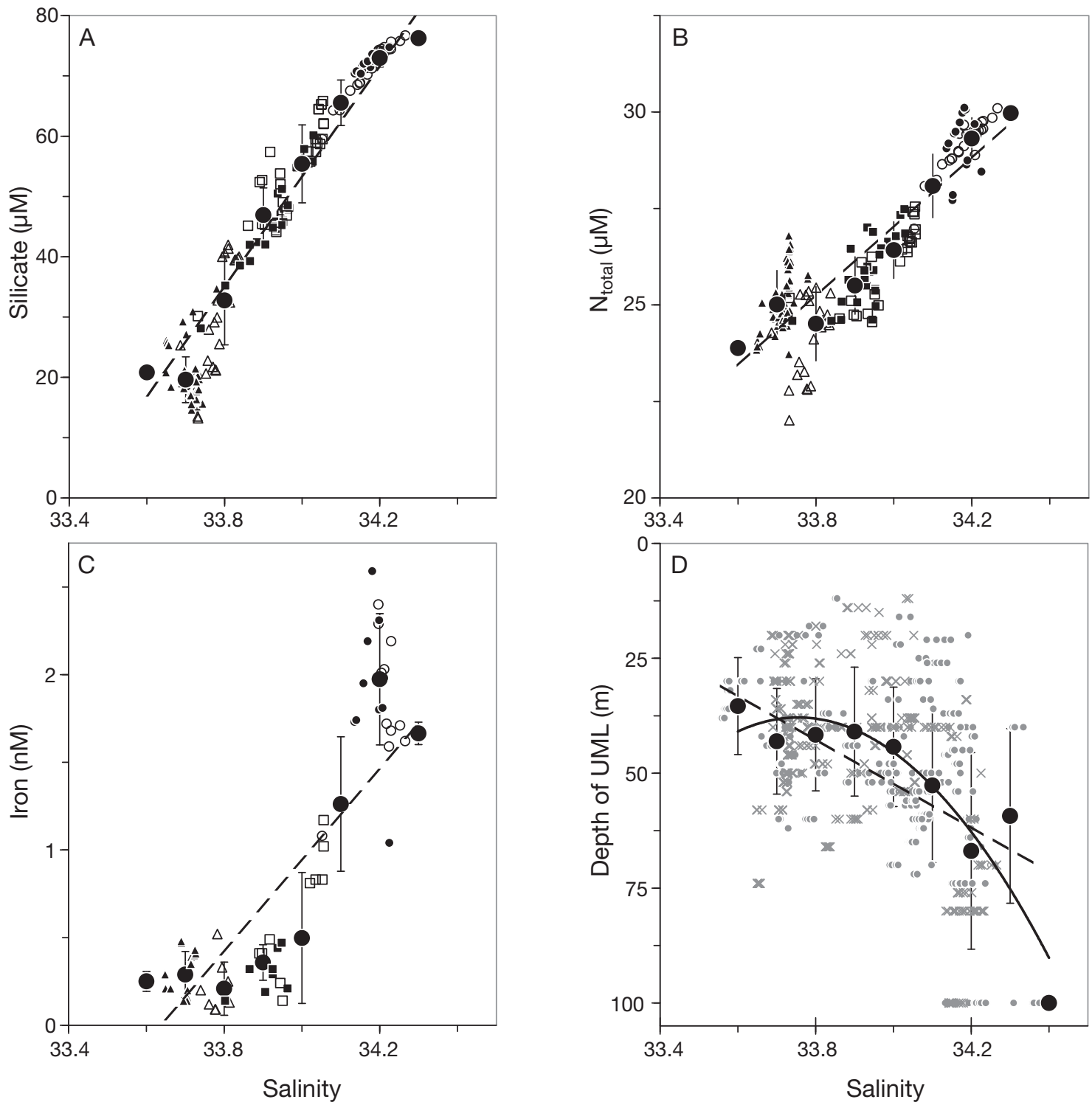

Fig. 3. Concentrations of (A) silicate, (B) total nitrogen, $N_{\text {total, }}$ and (C) iron versus salinity in the upper mixed layer (UML). Water zones are represented as WZ-1A $(\boldsymbol{\Delta})$, WZ-1B $(\Delta)$, WZ-2A $(\boldsymbol{\square})$, WZ-2B $(\square)$, WZ-3 (O), and WZ-4 () as in Fig. 2D. (D) Depth of the UML in relation to salinity for AMLR $(\bullet)$ and NSF $(\times)$ cruises, and 2nd order polynomial regression of all data drawn (solid curve). For A-D, linear regression shown by dashed lines $\left(A: r^{2}=0.9707 ; B: r^{2}=0.9378 ; C: r^{2}=0.7870 ; D: r^{2}=0.2550\right)$. Mean values $( \pm S D)$ of data at salinity increments of 0.1 are shown as large black filled circles (with error bars). For B-D, linear regressions against salinity (dashed lines) were used to derive a residual variability that was statistically examined in relation to PC axes

the range of salinity where macronutrients are high (Fig. 3A,B), iron exceeds $0.5 \mathrm{nM}$ (Fig. 3C) and where the UML shoals as the water freshens (Fig. 3D). On each side of the chl a maximum (salinity $~ 34$ ), either nutrients and iron were high, but surface waters were deeply mixed, or a shallow UML was present but iron concentrations were low. For salinities $<34$, there were no relationships between mean chl $a$ of the UML and UML depth (Fig. 5A), although WZ-1A waters had very low chl a values compared with the other water zones. For higher salinity waters, mean chl $a$ of the UML varied inversely to the depth of the UML (Fig. 5B) $(n=80$, $\left.\mathrm{r}^{2}>0.17, \mathrm{p}<0.001\right)$. The largest deviations from linearity for $\mathrm{N}_{\text {total }}$ and iron were at salinity $\sim 34$, where chl a was maximum. Importantly, the residuals of linear regressions for phosphate, $\mathrm{N}_{\text {total }}$ and iron with salinity (i.e. deviations from linearity with salinity in Fig. 3B,C) were negatively correlated with $\mathrm{chl} a$ concentration (phosphate: $\mathrm{n}=196, \mathrm{r}^{2}>0.33 ; \mathrm{N}_{\text {total }}: \mathrm{n}=196, \mathrm{r}^{2}>0.29$; iron: $\mathrm{n}=62, \mathrm{r}^{2}>0.41$, respectively) indicating that these losses were related to nutrient consumption. Furthermore, the above residuals between $\mathrm{N}_{\text {total }}$ and iron were highly correlated $(n=62, r>0.74)$, indicating that they co-vary across salinity. 

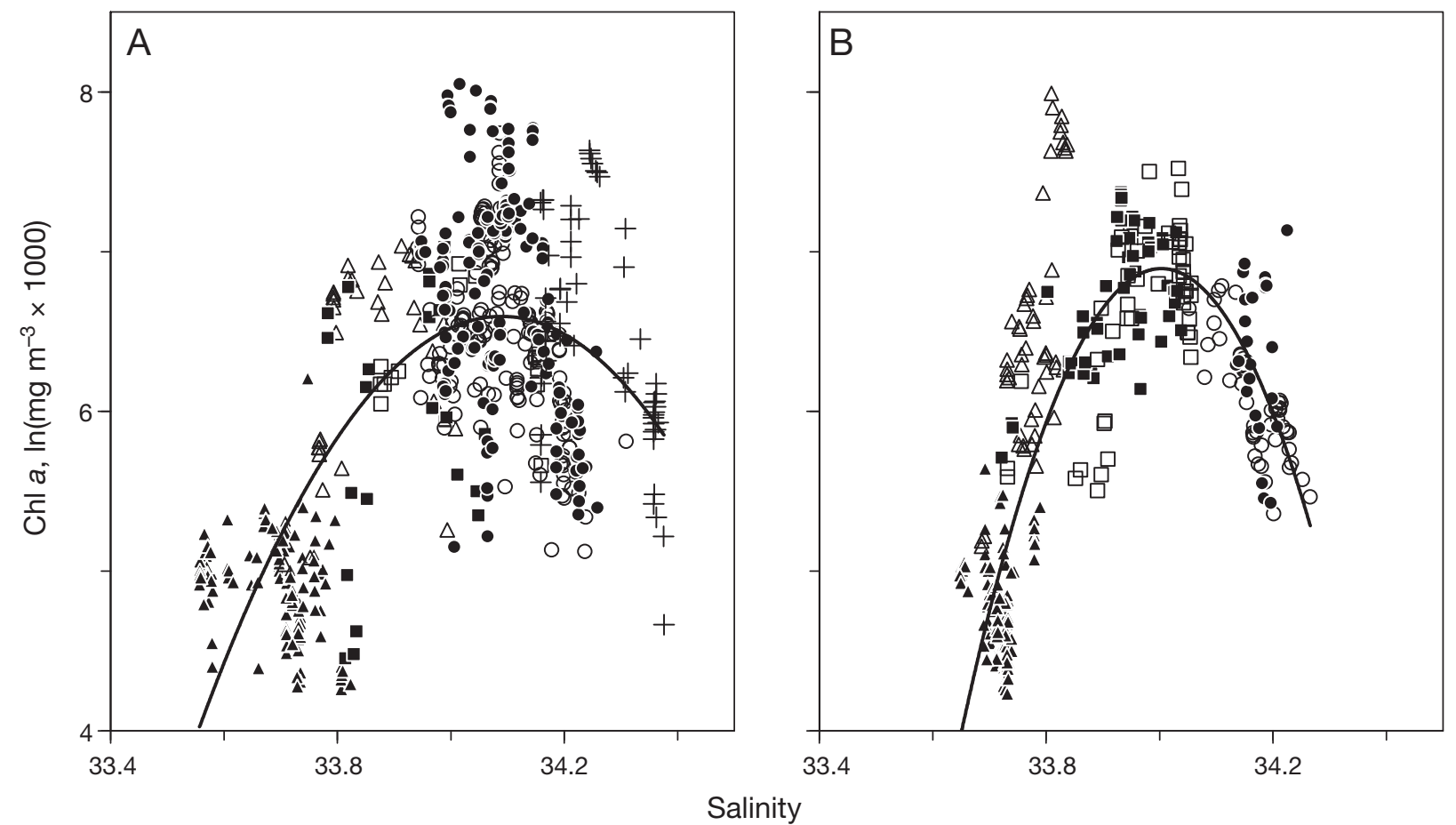

Fig. 4. Chl a concentrations in the upper mixed layer (UML) versus salinity for (A) AMLR and (B) LMG0402 cruises, February to March 2004 in the Elephant Island and South Shetland Islands region. Lines are 2nd-order polynomial regressions $(\mathrm{A}: \mathrm{n}=573$, $\left.r^{2}=0.489 ; B: n=394, r^{2}=0.668\right)$. Symbols as in Fig. 2D


Fig. 5. Mean chl a for the upper mixed layer (UML) plotted against depth of the UML for (A) salinities $<34$, and (B) salinities $>34$, with water zones indicated by the same symbols as in Fig. 2D. For salinities $<34$ (A), there is no relationship between UML depth and chl a (lines are regressions for WZ-1A, lowest, and all others), although WZ-1A $(\mathbf{\Delta})$ has much lower concentrations than any other water zone. For salinities $>34(B)$, chl $a$ and UML depth are inversely related $\left(n=80, r^{2}=0.179, p<0.001\right)$ 


\section{Determination of controlling factors}

Our data indicate that both hydrographic and chemical factors influence phytoplankton biomass, and these are highly correlated with the salinity gradient. PCA of environmental variables was used to derive a reduced number of linear, orthogonal (uncorrelated) independent axes to isolate and then evaluate factors related to the variability in phytoplankton biomass. We used only macronutrient $\left(\mathrm{N}_{\text {total}}\right.$, silicate, and phosphate), salinity, and UML depth data because $\sim 70 \%$ fewer stations were measured for trace metals (including iron) and because $\mathrm{N}_{\text {total }}$ was found to be a good proxy for iron concentration. A separate analysis that included iron (not presented) weakened the strength of the PCA because of the fewer data but did not alter results.

The first 3 principal components (PCs) accounted for more than $99 \%$ of the variability in nutrients and UML. Most $(83.1 \%)$ of this variability was described by PC1, while PC2 and PC3 accounted for 11.25 and $4.86 \%$ of the variability, respectively (Table 2 ). The factor loadings (Pearson's correlations between variables and each PC) indicate that environmental variables were negatively correlated with PC1 (Table 3). Several oceanographic and geographic variables not included in the PCA were also correlated with PC1 (Table 4).

Table 2. Eigenvalues of the principal component (PC) axes derived from principal component analysis (PCA) of macronutrient concentration, salinity, and upper mixed layer depth to explain chl a variability. Also listed are individual and $\mathrm{cu}-$ mulative percentages and scree plot for the individual axes

\begin{tabular}{|lcccc|}
\hline PC & Eigenvalue & $\begin{array}{c}\text { Individual } \\
\text { percent }\end{array}$ & $\begin{array}{c}\text { Cumulative } \\
\text { percent }\end{array}$ & $\begin{array}{c}\text { Scree } \\
\text { plot }\end{array}$ \\
\hline 1 & 4.9883 & 83.14 & 83.14 & |||||||||||||||||| \\
2 & 0.6748 & 11.25 & 94.39 & III \\
3 & 0.2918 & 4.86 & 99.25 & | \\
4 & 0.0224 & 0.37 & 99.62 & | \\
5 & 0.0183 & 0.31 & 99.93 & | \\
6 & 0.0041 & 0.07 & 100 & | \\
\hline
\end{tabular}

Table 3. Factor loadings (eigenvectors) for each of the 6 variables used for the PCA (see Table 2), with highest loadings for each $\mathrm{PC}$ in bold

\begin{tabular}{|llcc|}
\hline Variable & \multicolumn{1}{c}{ PC1 } & PC2 & PC3 \\
\hline Salinity & -0.9507 & 0.155 & -0.2458 \\
$\mathrm{UML}$ & -0.6218 & $\mathbf{- 0 . 7 7 8 7}$ & -0.0829 \\
$\mathrm{SiOH}$ & -0.924 & 0.1865 & $\mathbf{- 0 . 3 1 9 5}$ \\
$\mathrm{NO}_{3}$ & $\mathbf{- 0 . 9 8 1 7}$ & 0.0636 & 0.1535 \\
$\mathrm{PO}_{4}$ & -0.9642 & 0.0547 & 0.2364 \\
$\mathrm{~N}_{\text {total }}$ & -0.9747 & 0.0503 & 0.207 \\
\hline
\end{tabular}

For example, PC1 describes a latitudinal gradient between warmer and fresher (less dense) surface waters of the pelagic ocean (deeper ocean bottom) as they mixed with the cold and high saline (more dense) coastal waters (shallow bottom) from the south. Nutrients have high scores along this axis (Table 3 ), reflecting the co-linearity among them. Yet, salinity is also highly correlated with PC1, suggesting that PC1 is the primary linear gradient and a measure of conservative mixing, while lower PC axes describe the non-linearity of nutrients and UML depth in relation to salinity.

Since we interpret PC1 as describing the conservative mixing and dilution of nutrients (Table 4), the removal of the linear influence of salinity from the remaining variables should correspond with the remaining PCs. UML depth was the only variable that was highly correlated with PC2 and was uncorrelated with PC3 (Tables $3 \& 4$ ). The residuals of the UML depth vs. salinity regression were correlated with PC2 $\left(\mathrm{r}^{2}>0.26, \mathrm{p}<0.001\right)$, supporting our interpretation of the relationship of these 2 axes. UML depth was uncorrelated with PC3. In contrast, silicate and salinity were

Table 4. Correlation coefficients, $r$, for regression of various geographic, hydrographic, and biologic measurements in the upper mixed layer (UML) obtained during the 2-ship survey with the 3 significant PCs from the analysis results listed in Tables $2 \& 3$. Highly significant relationships $(\mathrm{r}>0.45)$ indicated by bold. Latitude is reflected by PC1, having increased bottom depth and surface temperatures (negative correlations being onshore to offshore), with highest salinities, nutrient/trace metal concentrations found in coastal waters and decreasing towards open ocean (positive correlations). Only depth of the UML was highly correlated with PC2. Chl $a$ and ammonia were highly correlated with PC3 that increased/ decreased in an easterly direction

\begin{tabular}{|lrrrr|}
\hline Variable & \multirow{2}{*}{$\mathrm{N}$} & \multicolumn{3}{c|}{ Correlation (r) } \\
& & PC1 & PC2 & \multicolumn{1}{c|}{ PC3 } \\
\hline WZ & 194 & $\mathbf{0 . 8 7 3 4}$ & 0.1664 & -0.2978 \\
Longitude & 194 & 0.2504 & 0.0781 & $\mathbf{- 0 . 4 7 7 1}$ \\
Latitude & 194 & $\mathbf{- 0 . 5 0 0 2}$ & -0.0346 & -0.2345 \\
Botttom depth & 194 & $\mathbf{- 0 . 4 5 2 2}$ & -0.1513 & 0.1559 \\
Sample depth & 194 & 0.4110 & -0.4156 & 0.0480 \\
Temperature & 194 & $\mathbf{- 0 . 8 9 2 1}$ & -0.0906 & 0.2291 \\
Salinity & 194 & $\mathbf{0 . 9 5 0 7}$ & 0.1562 & -0.2454 \\
Density & 194 & $\mathbf{0 . 9 4 9 2}$ & 0.1425 & -0.2528 \\
Oxygen & 180 & $\mathbf{0 . 5 6 9 6}$ & 0.3437 & -0.2573 \\
Depth of UML & 194 & $\mathbf{0 . 6 1 8 9}$ & $\mathbf{- 0 . 7 8 0 8}$ & -0.0854 \\
Silicate & 194 & $\mathbf{0 . 9 2 3 7}$ & 0.1892 & -0.3187 \\
Nitrate & 194 & $\mathbf{0 . 9 8 1 7}$ & 0.0624 & 0.1539 \\
Phosphate & 194 & $\mathbf{0 . 9 6 4 4}$ & 0.0539 & 0.2366 \\
Ammonia & 194 & 0.1761 & 0.0819 & $\mathbf{0 . 4 5 9 5}$ \\
N ${ }_{\text {total }}$ & 194 & $\mathbf{0 . 9 7 4 9}$ & 0.0500 & 0.2064 \\
rron & 62 & $\mathbf{0 . 9 4 0 8}$ & 0.0837 & 0.3022 \\
Manganese & 62 & $\mathbf{0 . 7 7 3 2}$ & 0.3899 & 0.1718 \\
Aluminum & 62 & $\mathbf{0 . 7 8 2 9}$ & 0.2142 & 0.2381 \\
log Chlorophyll & 194 & $\mathbf{0 . 3 4 8 3}$ & 0.3541 & $\mathbf{- 0 . 7 0 8 7}$ \\
\hline
\end{tabular}



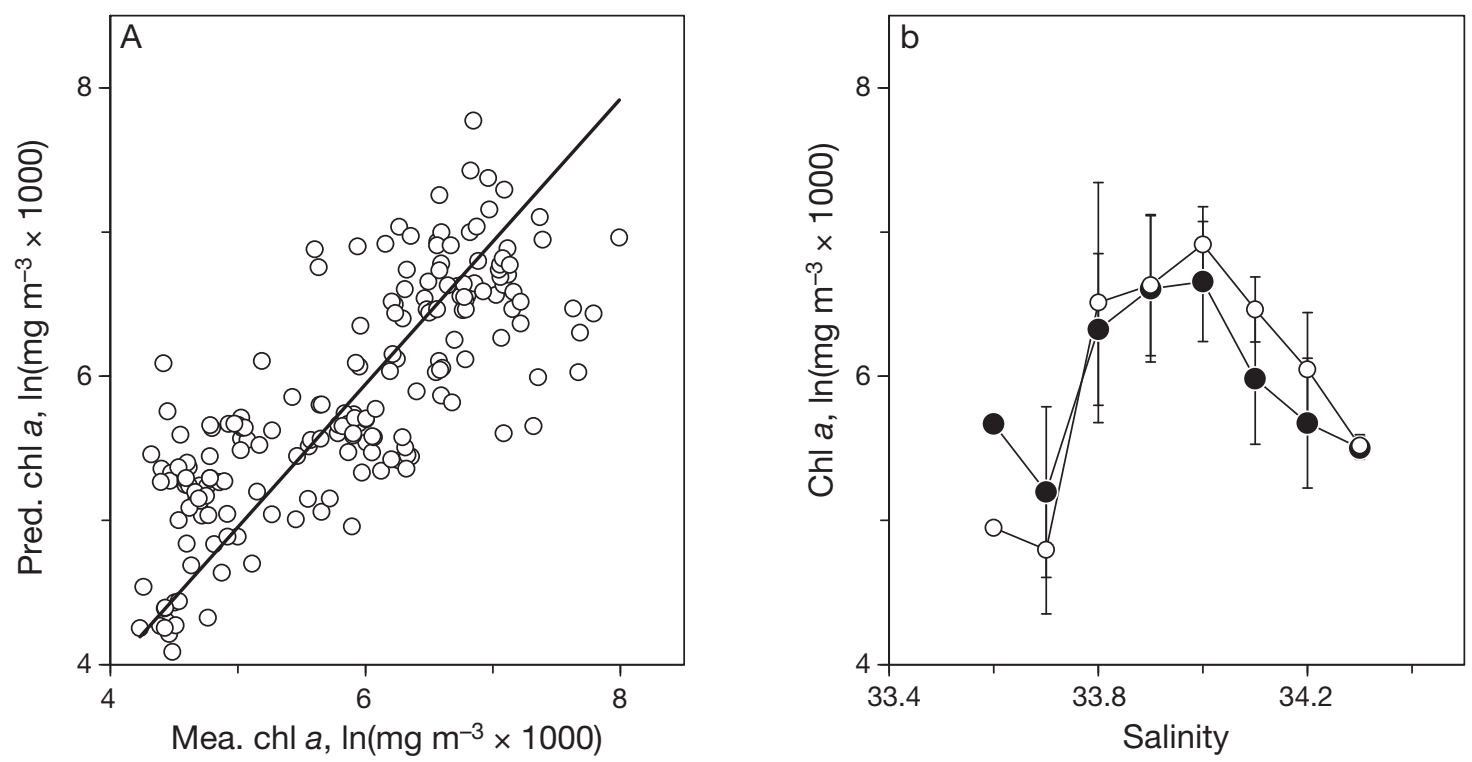

Fig. 6. Predicted chl a concentration as derived from a multiple regression of 2 significant principal components representing UML (PC2) and non-conservative nutrient loss (PC3). (A) Predicted chl a (Pred. chl a) vs. measured chl a (Mea. chl a) concentrations with regression line drawn $\left(\mathrm{y}=0.991 \mathrm{x}, \mathrm{r}^{2}=0.426\right)$. (B) Predicted $(\Theta)$ and observed (O) concentration of chl $a$ vs. salinity as average values $( \pm \mathrm{SD})$ of data at salinity increments of 0.1

negatively correlated with $\mathrm{PC} 3$, while the remaining nutrient concentrations were positively correlated with PC3 (Table 3). We interpret this pattern in PC3 as reflecting non-conservative losses (biological processes causing the non-linear deviations found for $\mathrm{N}_{\text {total }}$ and iron across salinity, Fig. 3B,C) that occurred simultaneous with mixing and dilution. For example, little correlation was found between nutrient/trace metal concentrations and PC3 (Table 4). Yet, the residual variability from linear regressions of nutrients vs. salinity (Fig. 3B) was highly correlated with PC3 $\left(\mathrm{r}^{2}>0.79,0.80\right.$, and 0.81 , for nitrate, $\mathrm{N}_{\text {total }}$ and phosphate, respectively), while silicate was weakly but oppositely correlated $\left(\mathrm{r}^{2}=0.18, \mathrm{p}<0.05\right)$. In addition, the residuals from the linear regression for iron vs. salinity (Fig. 3C) were also significantly correlated with PC3 $\left(\mathrm{r}^{2}>0.32\right)$, even though its data was not used in the PCA. Further evidence that PC3 represents non-conservative loss of nutrients (and iron) is that chl a was the most highly correlated variable with this axis (Table 4). Ammonium was also correlated with PC3 (Table 4). As chl a increased along $\mathrm{PC} 3, \mathrm{NH}_{4}$ declined further supporting our interpretation that this axis represents nonconservative loss of nutrients. Importantly, chl a was only weakly correlated with PC1 (Table 4), and it is reasonable to assume that as salinity itself is just a tracer of mixing, it would obscure the actual mechanisms controlling distribution of phytoplankton biomass as described by the lower PCs.

Results of a stepwise regression analysis (not shown) using all 3 PCs found that only PC2 and PC3 were important in explaining the variability of chl a (Fig. 6A) $\left(\mathrm{r}^{2}=0.65 ; \mathrm{p}<0.001\right)$, despite the nearly identical correlations of chl a with PC1 and PC2 (Table 4). Higher order interaction terms were not significant. The unimodal response of chl a across the salinity gradient was reconstructed using these 2 PCs (Fig. 6B). Although PC2 was highly significant $(p<0.0001)$ it accounted for only $8 \%$ of the chl a variability, while PC3 explained $>57 \%$ of it. This is interesting because PC2 explained considerably more of the variability in the data than PC3. We interpret this to mean that only a small range of UML depth is critical for the greatest non-conservative loss of nutrients through phytoplankton uptake.

\section{DISCUSSION}

Our data from the Elephant Island and South Shetland Islands area show that although upwelling at the Southern Boundary of the ACC occurred at depth (Fig. 2C), it was not responsible for nutrient distributions in surface waters, and was unlikely to be the dominant factor responsible for the distribution of phytoplankton biomass that we observed. Instead, we found that horizontal dilution of nutrients and changes in UML depth (Fig. 3) interacted to result in a unimodal distribution of phytoplankton biomass between the Weddell and the ACC (Fig. 4). Our multivariate analyses indicate that $>99 \%$ of variability is accounted for by just 3 PCs (Table 2) and that $65 \%$ of the variability 
of chl a distribution is reconstructed from PC2 and PC3 that describe UML depth and nutrient assimilation (Fig. 6).

The UML depth and the concentration of nutrients, as shown by the correlations in the PCA and related statistics, mediate the unimodal distribution of chl $a$ in the South Shetland Islands and Elephant Island area, although primary production in Antarctic waters might have a top-down control through predation (Hewes et al. 1985). Antarctic krill are the dominant zooplankton in bloom areas of the Southern Ocean (Smetacek et al. 2004), and within the SSI the highest abundance occurred between northeast of Elephant Island and the STR (WZ-2 and WZ-3, Fig. 1C) during our study period (Cossio \& Hewitt 2004). The highest concentrations of ammonia, a product of zooplankton excretion, were found in WZ-1 and WZ-3, and ammonia was negatively correlated with chl a along PC3 (Table 4). Since phytoplankton also assimilate ammonia, this negative correlation suggests that the rate of ammonia uptake by phytoplankton was greater than production of ammonia by zooplankton excretion at mid-salinities where chl a was highest. It seems, therefore, that grazing by zooplankton likely reduces the potential magnitude of chl a concentration across the salinity gradient, probably accounting for some of the remaining $35 \%$ of variability in chl a not explained by PC2 and PC3. The unimodal distribution of chl a across salinity thus appears to be primarily the function of both iron supply and UML depth.

Patterns of phytoplankton biomass observed in the western Antarctic Peninsular area have been explained as a function of upwelling of nutrient-rich UCDW (Prézelin et al. 2004). In contrast, we conclude that upwelling of nutrients from the UCDW was not the major factor controlling the nutrient and trace metal concentrations in surface waters during our study conducted during the austral summer. Evidence that upwelling was not the principle factor responsible for surface layer nutrient concentrations is apparent when the concentrations of trace metals in the UCDW ('ACClike' waters of the $27.6 \mathrm{~kg} \mathrm{~m}^{-3}$ isopycnal in Table 1), especially manganese, are compared with those found in shallower, sub-pycnocline WZ-2B waters (waters at the $27.4 \mathrm{~kg} \mathrm{~m}^{-3}$ isopycnal in Table 1). Additionally, when the silicate:nitrate ratios were compared between isopycnal surfaces within 'ACC-like' waters (Table 1), water on the $27.6 \mathrm{~kg} \mathrm{~m}^{-3}$ isopycnal surface had a higher value (2.2) than water on the shallower $27.4 \mathrm{~kg} \mathrm{~m}^{-3}$ isopycnal surface $(\sim 1.5$ to 1.9$)$. This difference resulted from the variability in nitrate, not silicate, along the $27.6 \mathrm{~kg} \mathrm{~m}^{-3}$ isopycnal surface. If, through upwelling, nutrient-rich deep water is pumped to the surface, it would need to mix with a source of low-salinity high-silicate water to produce the silicate:nitrate ratios at the salinities observed. Such a water mass does not exist in our area; the only fresher water source is the AASW (or glacial and ice melt) having low silicate concentrations. In addition, 'ACC-like' and 'Weddell-like' waters are completely isolated mixing regimes along the $27.6 \mathrm{~kg} \mathrm{~m}^{-3}$ isopycnal surface (Fig. 2C,D), so UCDW did not upwell along sloping isopycnals into the UML, in contrast to suggestions by Pollard et al. (2002, 2006). While WZ-1A through WZ-4 waters might mix across the $27.4 \mathrm{~kg} \mathrm{~m}^{-3}$ isopycnal surface (Fig. 2A), the ACC would be a sink, not a source, for iron and silicate (Table 1). Given these changes in nutrients and trace metals, the most likely explanation for their distribution in the UML is horizontal mixing and dilution of 'Weddell-like' waters by AASW from the ACC.

In the Elephant Island and South Shetland Islands region surface salinities decrease from the Antarctic Peninsula to the Drake Passage, and this change is paralleled in nutrient and trace metal concentrations (PC1 in Table 4). In general, nutrients and iron declined proportionately with declines in salinity, while chl a had a unimodal distribution across the salinity gradient (Fig. 4) and its maximum, which occurred at a salinity of $\sim 34$, coincided with both a shallow UML depth (Fig. 3D) and areas of substantial nutrient and trace metal concentrations (Fig. 3B,C). In other systems like the Ross Sea Gyre that is iron limited, latitudinal patterns in nutrients differ. For example, silicate decreases towards the ACC while nitrate increases (if at all). New production mostly occurs north of the Southern Boundary of the ACC after wintertime mixing re-supplies iron to the surface layer from the UCDW (Hiscock et al. 2003). In our study area, nutrients and trace metals deviated from salinity where phytoplankton biomass was high, indicating an area of enhanced nutrient consumption. $\mathrm{N}_{\text {total }}$ co-varied with iron indicating their non-conservative loss was tightly coupled. Thus, both conservative (mixing/dilution) and non-conservative (biological uptake) losses of nutrients in the UML explained their distributions in relation to salinity and chl a concentration. Further, high chl a concentrations also occurred where the UML depth had shoaled, suggesting that at intermediate salinities sufficient nutrients and light provide an environment conducive to enhanced phytoplankton production. Given the nutrient- and trace metal-replete conditions at salinities $>34$, it seems likely then, that the increased UML depth is the factor controlling the biomass in those waters.

Our analysis reiterates the relative importance of light-control for primary production owing to increased mixed layer depth under nutrient/trace metalreplete but deeply mixed conditions (Mitchell \& HolmHansen 1991), and under nutrient-control when the 
UML is shallow (WZ-1A waters, Fig. 3D) and the mean irradiance in the UML is close to, or exceeds, the value for light saturation $\left(\mathrm{I}_{\mathrm{m}}\right)$ of photosynthesis (HolmHansen \& Hewes 2004). The highest phytoplankton biomass occurred under nutrient/trace metal-replete conditions with UML depths $\sim 25$ to $50 \mathrm{~m}$ (Fig. 5), and before the dilution of iron became too low (salinities $<\sim 34$, Fig. 3C).

The individual and independent contributions of various nutrients, trace metals and hydrographic factors on the distribution and abundance of chl a concentration were inferred using PCA. PC1 accounted for most of the variability in the data (Table 3) and other variables in the region that change in an inshore-offshore direction (Table 4 ; see Orsi et al. 2005). Since the first PC was highly correlated with salinity (Tables $3 \& 4$ ) and therefore mixing and dilution, but not with chl $a$, its influence needed to be removed in order to clarify controlling mechanisms. Given the complicated change of UML depth across the salinity gradient, PCA was a better choice than simply standardizing the data set by dividing by salinity to remove the effect of dilution. The second and third PCs together predicted chl a better (Fig. 6) than any single measured variable (Table 4 ), or combination. That PC3 reflects loss of nutrients by biological uptake is apparent from Fig. 3 since the greatest non-linear change in nitrogen and iron concentrations corresponded with shoaling of the UML (Fig. 3D) and with high chl a concentrations (salinity 34, Fig. 4). Thus, PC analysis of the data describes an environmental space in which the effects of dilution (PC1) can be removed allowing the lower PCs to model potential mechanisms of bottom up control of phytoplankton biomass in this region. If this model is shown to be consistent amongst years, it will provide a simple set of testable predictions regarding variability in phytoplankton biomass as well as distribution and community structure that may be intimately linked to a dynamic balance resulting from horizontal mixing between the Weddell Sea outflow and the influx of ACC.

The AMLR study area is a biologically diverse region (Ducklow et al. 2007) that is experiencing some of the largest and fastest environmental changes in the Southern Hemisphere (Turner et al. 2005). Among the documented changes are warming of the air by $2.5^{\circ} \mathrm{C}$ since 1945 (Turner et al. 2005) and a decline in sea ice extent since at least the mid-1970s (Stammerjohn et. al. 2003). Gille (2002) showed that deeper waters of the ACC have also warmed, indicating that these changes are pervasive. We found that phytoplankton biomass varies in a predictable manner directly related to 2 variables likely influenced by climate: the nutrient (iron) flux from the Weddell Sea outflow into our area and surface water stratification derived from the ACC. Such environmental change will clearly impact the primary productivity of the system by altering nutrient inputs from coastal regions and upwelling as well as the stratification of the water column. Given the likely influence of atmospheric forcing in affecting outflow (Liu et al. 2002) and transport (White et al. 2004) of waters in this region, the tools provided here may simplify the manner by which we examine the biological effects of global climatic changes in the Elephant Island and South Shetland Islands region.

Acknowledgements. We thank the AMLR science team, the captain and crew of the RV 'Yuzhmorgeologiya', as well as the captain, crew, and RPSC support staff aboard the ARSV 'Laurence M. Gould' for all their shipboard help. Special thanks go to S. Gille, K. Barbeau and M. Zhou, for sharing ideas and comments regarding this work, and especially to C. Measures for letting us use his trace metal data. We also thank our 2 anonymous reviewers and editor, who helped improve this manuscript. This work was supported in part by the NSF Office of Polar Programs grant numbers: OPP0230433/ ANT0444134 (G. Mitchell). This work has also been funded in part to O. Holm-Hansen from the NOAA, USA Department of Commerce, under grant NA17RJ1231. The views expressed herein are those of the authors and do not necessarily reflect the views of NOAA, NSF or any of their sub-agencies.

\section{LITERATURE CITED}

Amos AF (1984) Distribution of krill (Euphausia superba) and the hydrography of the Southern Ocean: large-scale processes. J Crustac Biol 4:306-329

> Amos AF (2001) A decade of oceanographic variability in summertime near Elephant Island, Antarctica. J Geophys Res 106:22401-22423

Boyd PW (2004) Ironing out algal issues in the Southern Ocean. Science 304:396-397

Chisholm SW, Morel FMM (1991) What controls phytoplankton production in nutrient-rich areas of the open sea? Limnol Oceanogr 36:1507-1511

Cossio AM, Hewitt RP (2004) Bioacoustic survey. In: Lipsky J (ed) AMLR 2003/2004 Field season report: Objectives, accomplishments and tentative conclusions. NOAA-TMNMFS-SWFSC-367, p 46-52

De Baar HJW, Buma AGJ, Nolting RF, Cadee GC, Jacques G, Treguer PJ (1990) On iron limitation of the Southern Ocean: experimental observations in the Weddell and Scotia Seas. Mar Ecol Prog Ser 65:105-122

De Baar HJW, Boyd PW, Coale KH, Landry MR and others (2005) Synthesis of iron fertilization experiments: from the iron age in the age of enlightenment. J Geophys Res 110(C9), C09S16:1-24

Ducklow HW, Baker K, Martinson DG, Quetin LB and others (2007) Marine pelagic ecosystems: the West Antarctic Peninsula. Philos Trans Royal Soc B 362:67-94

Gille ST (2002) Warming of the Southern Ocean since the 1950s. Science 295:1275-1277

> Gordon AL, Mensch M, Dong Z, Smethie WM, de Bettencourt J (2000) Deep and bottom water of the Bransfield Strait eastern and central basins. J Geophys Res 105: 11337-11346 
Gordon LI, Jennings JC Jr, Ross AA (2001) A suggested protocol for continuous flow automated analysis of seawater nutrients using the Alpkem Flow Solution IV System. College of Oceanic and Atmospheric Sciences, Oregon State University, Corvallis, OR

Helbling EW, Amos AF, Silva N, Villafañe V, Holm-Hansen O (1993) Phytoplankton distribution and abundance as related to a frontal system north of Elephant Island, Antarctica. Antarctic Sci 5:25-36

Hewes CD, Holm-Hansen O, Sakshaug E (1985) Alternate carbon pathways at lower trophic levels in the Antarctic food-web. In: Siegfried WR, Condy PR, Laws RM (eds) Antarctic nutrient cycles and food webs. Fourth Symposium on Antarctic Biology (SCOR/SCAR), Wilderness, South Africa, 1983. Springer Verlag, Berlin, p 277-283

Heywood KJ, Naveira Garabato AC, Stevens DP, Muench RD (2004) On the fate of the Antarctic Slope Front and the origin of the Weddell Front. J Geophys Res 109:C06021, doi:10.1029/2003JC002053

Hiscock MA, Marra J, Smith WO Jr, Goericke R and others (2003) Primary productivity and its regulation in the Pacific sector of the Southern Ocean. Deep-Sea Res II 50: 533-558

Hofmann EE, Klinck JM, Lascara CM, Smith DA (1996) Water mass distribution and circulation west of the Antarctic Peninsula and including Bransfield Strait. In: Ross, RM, Hofmann EE, Quetin LB (eds) Foundations for ecological research west of the Antarctic Peninsula. American Geophysical Union, Washington, DC, p 61-80

> Holm-Hansen O, Hewes CD (2004) Deep chlorophyll-a maxima (DCMs) in Antarctic waters: I, Relationships between DCMs and the physical, chemical, and optical conditions in the upper water column. Polar Biol 27:699-710

Holm-Hansen O, Riemann B (1978) Chlorophyll a determination: improvements in methodology. Oikos 30:438-447

Holm-Hansen O, Mitchell BG, Hewes CD, Karl DM (1989) Phytoplankton blooms in the vicinity of Palmer Station, Antarctica. Polar Biol 10:49-57

Holm-Hansen O, Hewes CD, Villafañe VE, Helbling EW, Silva N, Amos A (1997) Phytoplankton biomass and distribution in relation to water masses around Elephant Island, Antarctica. Polar Biol 18:145-153

Holm-Hansen O, Kahru M, Hewes CD (2005) Deep chlorophyll a maxima (DCMs) in pelagic Antarctic waters. II. Relation to bathymetric features and dissolved iron concentrations. Mar Ecol Prog Ser 297:71-81

Legendre P, Legendre L (1998) Numerical ecology (Developments in environmental modelling), 2nd edn. Elsevier Science, New York

Letelier RM, Abbot MR, Karl DM (1997) Chlorophyll natural fluorescence response to upwelling events in the Southern Ocean. Geophys Res Lett 24:409-412

Liu J, Martinson DG, Yuan X, Rind D, Liu JP, Yuan XJ (2002) Evaluating Antarctic sea ice variability and its teleconnections in global climate models. Int J Climatol 22:885-900

Löscher BM, De Barr HJW, De Jong JTM, Veth C, Dehairs F (1997) The distribution of Fe in the Antarctic circumpolar Current. Deep-Sea Res II 44:143-187

Measures CI, Yuan J, Resing JA (1995) Determination of iron in seawater by flow injection analysis using in-line preconcentration and spectrophotometric detection. Mar Chem 50:3-12

> Mitchell BG, Holm-Hansen O (1991) Observations and modeling of the Antarctic phytoplankton crop in relation to mixing depth. Deep-Sea Res 38:981-1007

Nolting RF, de Baar HJW, van Bennekom AJ, Masson A, Bennekom AJ (1991) Cadmium, copper and iron in the Scotia
Sea, Weddell Sea and Weddell/Scotia Confluence (Antarctica). Mar Chem 35:219-243

Nowlin WD Jr, Zenk W (1988) Westward bottom currents along the margin of the South Shetland Island Arc. DeepSea Res 35:269-301

Orsi AH, Whitworth T, Nowlin WD Jr (1995) On the meridional extent and fronts of the Antarctic Circumpolar Current. Deep-Sea Res I 42:641-673

Orsi AH, Whitworth T, Sparrow M, Chapman P, Gould J (2005) Hydrographic atlas of the world ocean circulation experiment (WOCE) Vol 1: Southern Ocean. WOCE International Project Office, Southampton

Pollard RT, Lucas MI, Read JF (2002) Physical controls on biogeochemical zonation in the Southern Ocean. Deep-Sea Res II 49:3289-3305

Pollard RT, Tréguer P, Read JF (2006) Quantifying nutrient supply to the Southern Ocean. J Geophys Res 111:C05011, doi:10.1029/2005JC003076

Prézelin BB, Hofmann EE, Moline M, Klinck JM (2004) Physical forcing of phytoplankton community structure and primary production in continental shelf waters of the Western Antarctic Peninsula. J Mar Res 62:419-460

Priesendorfer RW (1988) Principal component analysis in oceanography and meteorology. Elsevier, New York

$>$ Resing J, Measures CI (1994) Fluorometric determination of A1 in seawater by FIA with in-line pre concentration. Anal Chem 66:4105-4111

> Resing JA, Mottl MJ (1992) Determination of manganese in seawater using flow injection analysis with on-line preconcentration and spectrophotometric detection. Anal Chem 64:2682-2687

> Sañudo-Wilhelmy SA, Olsen KA, Scelfo JM, Foster TD, Flegal AR (2002) Trace metal distributions off the Antarctic Peninsula in the Weddell Sea. Mar Chem 77:157-170

Smetacek V, Assmy P, Henjes J (2004) The role of grazing in structuring Southern Ocean pelagic ecosystems and biogeochemical cycles. Antarct Sci 16:541-558

Smith WO, Nelson DM (1985) Phytoplankton bloom produced by receding ice edge in the Ross Sea: spatial coherence with the density field. Science 227:163-165

> Stammerjohn SE, Drinkwater MR, Smith RC, Liu X (2003) Iceatmosphere interactions during sea-ice advance and retreat in the western Antarctic Peninsula region. J Geophys Res 108(C10):3329, doi:10.1029/2002JC001543

> Strass VH, Naveira Garabato AC, Pollard RT, Fischer HI and others (2002) Mesoscale frontal dynamics: shaping the environment of primary production in the Antarctic Circumpolar Current. Deep-Sea Res II 49:3735-3769

ter Braak CJF (1987) Ordination. In: Jongman RHG, ter Braak CJF, van Tongeren OFR (eds) Data analysis in community and landscape ecology. PUDOC, Wageningen, p 91-173

- Turner J, Colwell SR, Marshall GJ, Lachlan-Cope TA and others (2005) Antarctic climate change during the last 50 years. Int J Climatol 25:279-294

- Tynan CT (1998) Ecological importance of the Southern Boundary of the Antarctic Circumpolar Current. Nature 392:708-710

Westerlund S, Öhman P (1991) Iron in the water column of the Weddell Sea. Mar Chem 35:199-217

> White WB, Gloersen P, Simmonds I (2004) Tropospheric response in the Antarctic Circumpolar Wave along the sea ice edge around Antarctica. J Clim 17:2765-2779

Whitworth T, Nowlin W, Orsi A, Locarnini R, Smith S (1994) Weddell Sea shelf water in the Bransfield Strait and Weddell Scotia Confluence. Deep-Sea Res 41:629-641 